\title{
Popular Media and Postmodernism in the Age of the TV Talk Show
}

\author{
Christoph Lindner \\ University of Edinburgh
}

\section{TRASHTV}

These days it is hard to tune into daytime or late night television without coming across a TV talk show of sorne kind. From Oprah to The Jerry Springer Show, the range is stunning. In the US alone, viewers can choose on any given day between over 20 nationally syndicated talks shows. The range of topics on these shows is equally stunning, featuring everything from alien abduction and teenage pregnancy to racism and vampirism. The outrageous, bizarre, and often disturbing social behavior so gleefully paraded about on contemporary TV talk shows makes it clear that airing out our dirty laundry on national television is now an enormously popular form of entertainment.

In a 1995 edition of American TV Cuide, Oprah Winfrey (aka "The Queen of Trash") spoke out against contemporary TV talk shows-that is, against the very broadcasting genre and cultural phenomenon she helped to create:

We started doing confrontational TV ... I believed it was important to introduce these issues and face the truth of who we were .... Instead, TV got stuck on them, and for the worst possible reasons--exploitation, voyeurism, and entertainment. (Abt \& Mustazza 1)

As the pioneer of the age of the TV talk show, Oprah knows what she's talking about here. In the mid 1980's she effectively transformed the TV talk show into a successful medium for voyeuristic sensationalism: a public space for the airing out of society's dirty laundry; a public forum for spontaneous confession, confrontation and debate; a gratuitous freak show of the bizarre, the grotesque, and the fantastic. In short, Oprah gave us 'Trash TV.' And though she has voluntarily toned down her act in recent years, spin-off programmes like Ricki Lake, Geraldo, Jenny iones, and, most of all, The Jerry Springer Show continue to reach new heights of unrestrained and shameless exhibitionism.

In Britain for example this was made when, in October 1998, Channel 4 aired one of its fir"t "X-Rated Ricki" programmes-a Ricki Lake special featuring professional strippers strul'ting their stuff and giving advice on breast enlargements and weight loss. As Jerry Springer admitted to Entertainment Weekly a few years back, the rationale behind this kind of broaldcasting is simple: "the more controversia\}, the bigger the show gets" (Jacobs 34). The effe-ct of the highly-publicized murder of a Jenny Jones guest in 1995 following the taping of her show further corroborates this view. After the murder, the programme's popularity actually increased. When it comes to TV talk shows, it would seem the circus king P. T. Barri'llm had it right when he said there is no such thing as bad publicity. 
In an industry dominated by a cut-throat competitive mentality - where hosts vie on a daily basis to out-perform and, above all, out-sell one another-talk television's spirit of contest and extremism have reached critical mass. In fact, in its continuing search for exploitable material, Trash TV has even turned on itself, producing salacious talk shows about the salaciousness of talk shows. Confronted by this apparently absurd state of affairs, media analysts Vicki Abt and Leonard Mustazza find that the situation has become so parodic that it practically defies further attempts at parody: "it is, of course, impossible to satirize what is already parody and travesty" (15). MTV, however, manages to do just that in a 1997 episode of its comedy programme, Celebrity Death Match.

The episode in question features clay models of American talk show hosts Rosie O'Donnel and Oprah Winfrey fighting it out in a no-holds-barred wrestling extravaganza. At stake in this wrestling match is the coveted title of "The Queen of Trash," currently held by Oprah Winfrey, the undisputed world champion. Dressed in skin-tight leotards, Oprah and Rosie proceed to kick, strangle, bite, slug, and body slam each other with vindictive ruthlessness. To top it off, the bout ends with a clay model of Jerry Springer, also dressed in a leotard, parachuting into the ring. Knocking down both Oprah and Rosie as he lands, Jerry asks in a trade-mark 'final thought' moment whether anyone has ever heard of quality programming. Apparently he hasn't, since he goes on to challenge both female 'contenders' to a televised three-way cage fight. As Jerry Springer's clay figure explains it, this is "the dreaded no holds barred steel cage dance of death. Three talk show hosts go into the cage, and only one comes out. Its thaaaaat simple!" Basically, if we take the TV talk show as in part a parody of popular culture, this episode of Celebrity Death Match can be seen as a deliberate parody of that parody.

Though MTV may be grossly over-simplifying the situation here, this episode of Celebrity Death Match does successfully translate the confrontational and performative ethic of the TV talk show into that of a WWF-style wrestling match. That the translation works effortlessly in this setting, and that audiences can actually get the jokes, would indicate that this seemingly far-fetched scenario is actually far more accurate than we might first assume in its underlying conception of the talk show's dynamic. Moreover, the episode captures perfectly, if somewhat absurdly, the 'celebrity death-match' mentality that largely overshadows the mediation of popular culture in and through 'Trash TV.'

On the topic of 'Trash TV,' Abt and Mustazza propose that talk television can be seen as "a microcosm of ... popular culture and the commercial interests that manufacture and sustain it" (9). I would agree with this up to a point. Granted, talk television does reflect many of the interests, concerns, and activities of popular culture today. Similarly the corporate economics of TV broadcasting and advertizing have much to say about its wider production and dissemination. But talk television, we should remember, goes deliberately out of its way to showcase the anomalous. What it delivers, then, is not exactly a microcosm, but more a carefully edited, highly-stylized, and contrived representation of popular culture in its most scandalous forms. This is not the thing itself, in other words, but a mediated image of the thing itself - a spectacle in the full sense that Guy Debord gives to the word (12). In short, the age of the TV talk show is part and parcel of what Ihab Hassan, following 
Baudrillard, calls the postmodern "age of disseminated simulacra" (7). In many ways, MTV's Celebrity Death Match can be seen as its expression par excellence. It makes a spectacle of a spectacle. It simulates a simulation. It functions solely within the realm of Baudrillard's hyperreal, of that which is "always already reproduced" (142).

Taken together, the format, material, and, above all, success of contemporary TV talk shows effectively illustrate what popular culture in the postmodern era demands and expects from the 'disseminated simulacra' of its representational media-namely, as Oprah complains, exploitation, voyeurism, and entertainment. What I want to suggest now is that, like the metacommentary of MTV's Celebrity Death Match, Oprah's comments about 'Trash TV' equally apply to how popular media, in turn, receive and represent the idea of the postmodern.

\section{TOXIC TALK}

Over the course of the last decade, the idea that we live in a postmodern era-that our current cultural climate somehow possesses an acutely postmodern character-has increasingly gained currency in the discourses of popular culture. From film to public sculpture, from club music to advertising, and from industrial design to cartooning, popular culture today is overwhelmed with the project of expressing its postmodern personality. In so doing, it has effectively transformed the mediation of the postmodern condition into a multi-media public spectacle. Popular media, in the process, have subjected postmodernism to the same kinds of sensational reportage we know and recognize so well in the format of contemporary TV talk shows. This, in turn, has led to a popular perception of postmodernism as somehow inimical to the values and practices of contemporary society.

In December 1998, there appeared in the op-ed section of The New York Times an irreverent spoof on the postmodern condition, titled Geraldo, Eat Your Avant-Pop Heart Out, which articulates these points exactly. Written by Mark Leyner, it takes the shape of a fictional transcript from the American talk show, Jenny Jones. In this case, the 'show' consists of an interview with an author, a recovering postmodernist, who goes by the pseudonym of 'Alex.' In the course of the interview, Alex claims that postmodernism has destroyed his identity. His story runs like this.

Alex first experimented with postmodernism at the age of nine when he started dipping into Jameson. It was only a matter of time before he moved on to the hard stuff, and by his early teens he was hooked on the likes of Baudrillard and Lyotard. At 14 he was, in his own words, finally ruined by Deleuze and Guattari. Around this time, he was arrested for "spray-painting 'The Hermeneutics of Indeterminacy' on an overpass" (11). Now, Alex maintains that under the influence of postmodern theory his creative writing and personal life have been irreparably damaged. Both have become increasingly disjunctive, facetious, and parodic-ironies wrapped in more ironies. In short, Alex arrives at the same opinion as the philosopher Richard Rorty who is quoted in another New York Times article as saying that "nobody has the foggiest idea what postmodernism means" and that "postmodernism is only a word that pretends to stand for an idea" (in Scott 24). So Alex feels defrauded by the 
academics who, he believes, have promoted postmodern theories knowing all along that they were just an intellectual scam. What does Alex do about it? He decides to sue the Modern Language Association.

However absurd, the format of Leyner's piece-namely, that of a TV talk-show taken to a farcical extreme-does raise interesting questions about how the postmodern figures in and through the lens of popular media. To begin, Leyner's spoof consciously attacks postmodernism on several fronts. It denounces the postmodern condition and its theorization as essentially paralyzing and nihilistic. Postmodernism, we hear, reduces the subject to a parody of itself. It posits identity and its constituent parts as nothing more than spurious inventions of language. And, just like talk television, it promotes what Alex calls "the selfconscious recycling of cultural detritus" (11). Thanks to postmodern thought, there is nothing left to represent but representation itself. Or so Alex would have it, as this extract from the talk show's 'transcript' highlights:

JENNY JONES: Tell us how you think postmodernism affected your career as a novelist. ALEX: I disavowed writing that contained any real ideas or any real passion . . . . It was all blank parody .... . It merely recapitulated the pernicious banality of television and advertizing. I found myself indiscriminately incorporating all kinds of pop kitsch and schlock. (He begins to weep again.)

JENNY JONES: And this spilled over into your personal life?

ALEX: It was impossible for me to experience life with any emotional intensity. I couldn't control the irony anymore. I perceived my own feelings as if they were in quotes.

I italicized everything and everyone. It became impossible for me to evaluate the quality of anything. To me everything was equivalent - the Brandenburg Concertos and the Lysol jingle had the same value .... (He breaks down, sobbing.) (11)

In the Postmodern Condition, Lyotard concludes by urging us to "wage war against totality," to witness "the unpresentable" and to "activate the differences" (82). In the preceeding extract from the fictional 'transcript,' we almost get the sense that Leyner wants to demonstrate what can happen to those who take Lyotard's call to arms far too literally. Alex's semantic war on totality results not in some playful affirmation of the Lyotardian differend, but in the total psychological collapse of identity itself.

In short, the spoof ultimately makes a point of presenting postmodernism as fundamentally hostile towards modernity's founding assumptions about identity, agency and project. For in the end, what Alex is really accusing postmodernism of doing is not destroying the subject, but rewriting modernity's constructions of it. Yet Leyner's spoof is itself equally guilty of the charges it makes against postmodernism. The spoof self-consciously recycles the very cultural detritus it sees as cultural detritus, deliberately reducing the idea of the postmodern to a bland parody of itself. And it not only sets out to trash postmodernism, but does so by employing distinctively postmodern strategies of representation. It sets out, in so many words, to turn postmodernism on itself.

It is here that the format of the TV talk show comes back into play. By using this format, Mark Leyner makes his agenda explicit. By definition, 'Trash TV' deals in trash. So we already know exactly what to expect from Leyner's treatment of the topic. And true to the genre of 'Trash TV,' this 'show' goes well out of its way to trivialize and sensationalize 
the postmodern. At the same time, however, the format of the TV talk show immediately flags the fact that what the 'show' delivers is a staged spectacle. And like the TV talk show it pretends to be, this fictional and simulated one similarly delivers a highly-stylized and contrived representation. This is not the thing itself but, again, a mediated image of the thing itself. In this case, we look at postmodernism through the biased lens of a popular democratic tradition of identity politics that always already sees it as an empty and selfdeluding gesture.

Far from exceptional, the kind of sensational reportage we find in Geraldo, Eat Your Avant Pop-Heart Out is largely characteristic of popular media's explicit treatment of postmodernism. Richard Rorty's reported comments in The New York Times, published only a month before Leyner's piece, make another good example. In less than two columninches, Rorty boldly dismisses postmodernism as the most overrated idea of the twentieth century, arguing not only that nobody knows what it means but also, and more revealingly, that "the idea one ought to get rid of is that there is any need to get beyond modernity" (Scott 24). If we consider Rorty's many contributions to the theorizing of postmodernity, his comments are nothing short of inflammatory, so that the paper's decision to print them smacks of deliberate sensationalism. Significantly, we once more witness a nostalgia for modernity's fixed and stable categories, what Lyotard brands the "nostalgia of the whole and the one" (82). And no wonder, really, when faced with the postmodern alternative-as least in these accounts-of endless, solipsistic play.

Popular media's representation of the postmodern is overwhelmed by precisely the kinds of controversial, slanderous, and spectacular visions we find in Leyner's spoof and even Richard Rorty's reported comments. These spectacles, however, are not innocuous entertainment. Not only do they reflect wider public concerns about postmodernity's social and political impact, but more importantly they inform popular opinion. In a way, popular media are engaged in exacerbating the very anxieties they helped to create in the first place. As with Oprah and 'Trash TV,' their sensational reports are complicit in the cultural phenomena and representational projects they set out to disclaim.

Linda Hutcheon rightly points out that, from the beginning, the cultural theorization of postmodernism has been accompanied "by a flourish of negativized rhetoric: we hear of discontinuity, disruption, dislocation, decentering, indeterminacy and anti-totalization" (3). These "disavowing prefixes" (3), as she calls them, are slowly losing their purchase on the discourses of cultural theory. Yet this glut of toxic talk nonetheless remains integral to the discourses of popular culture and its media. We hear of postmodernism as a word that masquerades as an idea, as an intellectual scam, as an act of philosophical suicide, even as an addiction to be overcome.

It has now been over a decade since Ihab Hassan urged that "the time has come to theorize the term postmodernism, if not define it, before it fades from awkward neologism to derelict cliché without ever attaining to the dignity of a cultural concept" (Hutcheon 3). In disciplines across the humanities and social sciences, cultural thinkers have now widely risen to the challenges of theorizing the postmodern. But popular culture and its media have yet to concede it much importance. They have yet to engage with postmodernism responsi- 
bly or even seriously. As it stands now, the word 'postmodernism' has already faded to a derelict and annoying cliché in the public mind. Yet, if popular culture is to begin seeing the postmodern as something more than an unwelcome and awkward presence in today's political and cultural arenas-as anything other than inimical to the values and practices of contemporary society - then popular media need to refocus their lens. They need to shed their talk show ethic, lose the Celebrity Death Match mentality, and begin by affording the idea of the postmodern the basic legitimacy of a cultural concept.

\section{WORKS CITED}

Abt, Vicki, and Leonard Mustazza. Coming After Oprah: Cultural Fallout in the Age of the TV Talk Show. Bowling Green: Popular Press, 1997.

Baudrillard, Jean. Simulations. Trans. P. Beitchman. New York: Semiotexte, 1983.

Debord, Guy. Society of the Spectacle. Trans. Donald Nicholson-Smith. New York: Zone Books, 1994.

Hassan, Ihab. "Ideology, Theory, and the Self: Toward an Independent Criticism." Criticism in the Twilight Zone: Postmodern Perspectives on Literature and Politics. Ed. Danuta Zadworna-Fjellestad. Stockholm: Almqvist \& Wiskell, 1990. 1-15.

Hutcheon, Linda. A Poetics of Postmodernism: History, Theory, Fiction. London: Routledge, 1988.

Jacobs, A. J. "On the Wild Side: It's All in a Day of Daytime Trash at the Jerry Springer Show.” Entertainment Weekly. May 12 1995: 34-7.

Leyner, Mark. "Geraldo, Eat Your Avant-Pop Heart Out." The New York Times Dec. 21 1998: D 11.

Lyotard, Jean-Francois. The Postmodern Condition. Trans. R. Durand. Manchester: MUP, 1986.

Scott, Janny. "Lofty Ideas That May Be Losing Altitude." The New York Times Nov. 1 1998: 24. 